\title{
NATIONALITY INTERNATIONAL: DETECTIVE FICTION IN THE LATE TWENTIETH CENTURY
}

\author{
EVA ERDMANN
}

At the beginning of the twenty-first century, crime fiction is a topranking literary genre, and has become part of mainstream culture. The crime novel's position of pre-eminence derives from its broad fan base and its readership, with publishing houses devoting whole series and large print runs to the genre. ${ }^{1}$ Evidence of the prevalence of a popular obsession with crime stories is also to be found in the sophisticated typological variety of crime fiction, present in literature and in film. Readers who favour novels with female detectives are not necessarily enamoured of ethno-detective novels, while hard-boiled thrillers differ significantly from fantasy detective fiction. Among the television shows starring detectives, every variety of the genre is represented. In recent decades we have also seen crime fiction gain in popularity in the spheres of literary experiment ${ }^{2}$ and literary theory. ${ }^{3}$

\footnotetext{
Examples include DuMont's and Rowohlt's crime series on the German book market, the gialli in Italy and Gallimard's folio policier in France.

2 Recent novels whose narrative model is based on that of the detective story include: Georg Klein, Barbar Rosa: Eine Detektivgeschichte (Berlin: Alexander Fest, 2001); Thomas Hettche, Der Fall Arbogast (Cologne: DuMont, 2001); Haruki Murakami, A Wild Sheep Chase (Tokyo: Kodansha International, 1989 originally published as Hitsuji wo meguru Bohken, 1982); and Paul Auster, Leviathan (New York: Faber and Faber, 1992).

3 The frequently repeated schema of the thriller plot seduces the reader into abstract reflections on trails of suspicion, victims or suspicion itself. For a theoretical basis, see Tzvetan Todorov, "Typologie du roman policier", in Poétique de la prose, Paris: Seuil, 1971; Hans Sanders, "Die Welt ist, was der Fall ist: Poetologische Randnotizen zum Kriminalroman", Romanistische Zeitschrift für Literaturgeschichte/Cahiers d'Histoire des Littératures Romanes, XVII/3-4 (1993), 387-403.
}

Konstanzer Online-Publikations-System (KOPS) URN: http://nbn-resolving.de/urn:nbn:de:bsz:352-opus-76545 URL: http://kops.ub.uni-konstanz.de/volltexte/2009/7654 
The pursuit of criminals and the solving of crime have developed into a cultural code, even a cultural ritual.

Since the Seventies, there has been a real boom in crime fiction, with many new authors adopting the genre. The dominant form is the series detective novel where each book is complete in itself, but the same protagonist or protagonists appear in succeeding books. The interest resides equally in the solution of different cases and in the representation of the detective's daily life. Professional and personal successes or crises are given equal attention in this new crime fiction. Surprisingly, the crime novel of the last decades is distinguished by the fact that the main focus is not on the crime itself, but on the setting, the place where the detective and the victims live and to which they are bound by ties of attachment. The surroundings where the investigations take place are portrayed with increasing inventiveness, to the extent that the crime itself appears to be at best merely a successful stunt. It almost seems as if the inventories of criminal motives and case histories have been exhausted, so that crime fiction's primary distinguishing characteristic has become the locus criminalis.

While serialization becomes more common, the cultural surroundings become more and more original. Social, cultural, historical and political conditions become the object of exhaustive inquiries. We find, for example, descriptions of daily life in the kibbutz, ${ }^{4}$ British class snobbery in its everyday garb, ${ }^{5}$ images of women being updated, ${ }^{6}$ and analyses of the era of Franco's dictatorship in Spain. ${ }^{7}$

4 See Batya Gur, Murder on a Kibbutz: A Communal Case, New York: Harper Collins, 1995.

5 The unbalanced detective duo of Elizabeth George's novels, Thomas Lynley and Barbara Havers, ensure continuing conflicts (both comic and serious) between the upper class and a weak middle class. See, for example, A Great Deliverance, 1988; Missing Joseph, 1993; Payment in Blood, 1989; Well-schooled in Murder, 1990; A Suitable Vengeance, 1991; For the Sake of Elena, 1992; Playing for the Ashes, 1994, among others (all London: Bantam).

6 Three very different examples of female detective stories with their different images of women illustrate the current diversity: the lecturer in literature, Kate Franzler, in the crime novels of Amanda Cross; the middle-aged commissioner in Doris Gercke's novels; the unmarried private detective in Valerie Wilson Wesley's books.

7 For a more detailed discussion of this, see Stewart King's essay on Manuel Vázquez Montalbán in this collection. 
Detective fiction written in the last decades is more suitable for comparative study than almost any other material, for the tertium comparationis, the fixed course of events in the genre, remains the same - first murder, then suspicion, sometimes a false trail, and in the end, resolution. It is the wide variety of new scenes of the crime that ensures that contrasts exist between the various novels. In recent decades, detective fiction has described so many customs and mores from different parts of the world that it is impossible to get an overview. The treatments of them are so detailed that many detective novels can also be considered milieu studies and social novels. Until now, the majority of analyses of current crime fiction, both in literature and film, have taken a monographic approach or followed a logic of genre or national philology. They have only seldom gone beyond the limits of such a focus. ${ }^{8}$

\section{Global crime}

In literature, the spread of crime has taken on topographic proportions that reflect the globalization processes of the late twentieth century. In crime novels at the beginning of the twenty-first century, investigations take place all over the world and anyone who went to the trouble of totting up the sum of fictional scenes of the crime would be undertaking a project of international cartography. On the map of the world there are hardly any areas uncharted by crime fiction, hardly any places that have not yet become the setting for a detective novel.

Criminal investigations have been pursued in Newark by Tamara Hayle (Valerie Wilson Wesley) and in the Bahnhofsviertel, the red

8 For a comparative examination that goes beyond national and linguistic boundaries, see Ulrike Leonhardt, Mord ist ihr Beruf: Eine Geschichte des Kriminalromans, Munich: C. H. Beck, 1990; Jochen Schmidt, Gangster, Opfer, Detektive: Eine Typengeschichte des Kriminalromans, Frankfurt am Main: Ullstein, 1987; and Joan Ramon Resina, El cadáver en la cocina: La novela criminal en la cultura del desencanto, Barcelona: Anthropos, 1997. On the issue of genre, see Ulrich Schulz-Buschhaus, Formen und Ideologien des Kriminalromans: Ein gattungsgeschichtlicher Essay, Frankfurt am Main: Athenaion, 1975. For film and cinematic history of the genre, see Georg Seeßlen, Detektive: Mord im Kino, Marburg: Schüren, 1998 and Zur Geschichte des Kriminalfilms: Arbeitsheft zur Schulfernsehsendung "Der Fall Derrick", Berlin: Wissenschaftlicher Verlag, 1987. 
light district in Frankfurt by Kemal Kayankaya (Jakob Arjouni), ${ }^{9}$ in Berlin by Karin Lietze (Pieke Biermann), in Marseilles by Fabio Montale (Jean-Claude Izzo), ${ }^{10}$ in the Belleville quarter of Paris by Malaussène (Daniel Pennac), in London by Helen West and Geoffrey Bailey (Frances Fyfield) as well as Chief Inspector Reginald Wexford (Ruth Rendell), in Zaïre (Achille F. Ngoye), in Moscow (Alexandra Marinina) ${ }_{1}^{11}$ in Japan (Sujata Massey), in Helsinki (Jouko Raivio), in the North of England (Val McDermid), in Edinburgh (Ian Rankin), in Greece (Petros Markaris), in China (Wang Shuo), in Canada, Cuba, Mexico, Australia, and in Algeria. ${ }^{12}$ In recent decades, detective stories in film and literature have been set in many different locations. European detective fiction production no longer takes second place to American, even though the USA still leaves its traces conceptually and intertextually in individual works. ${ }^{13}$

Crime plots have been located on every continent and in every country, even in the remotest of places. Until the middle of the twentieth century, the classic works of European detective fiction, the cases investigated by Commissioner Maigret and those of Nestor Burma, were directly associated with French metropolitan flair and the Quai d'Orfèvres was known even to those who had never been to Paris. Now, formerly privileged settings for crime such as Paris have given way to the omnipresence of crime and the cities must vie for attention with the provinces. This merely reflects the fact that from the earliest times, village gossip and family histories have been an inexhaustible source of inspiration for storytellers.

In the early twentieth century, the French and the English crime series were already well established, and the plot of a detective novel

9 Jakob Arjouni and his work are discussed in detail in Arlene Teraoka's essay in this collection.

10 For a more detailed discussion of Jean-Claude Izzo, see Agnès Maillot's essay in this collection.

11 For further details on both Marinina and contemporary Russian crime narrative, see Willem G. Weststeijn's essay in this collection.

12 On the Algerian crime novel, see Beate Burtscher-Bechter, Algerien - ein Land sucht seine Mörder: Die Entwicklung des frankophonen algerischen Kriminalromans (1970-1998), Frankfurt am Main: IKO, 1999, and see also her essay in this collection.

13 See Anne Mullen and Emer O'Beirne, Crime Scenes: Detective Narratives in European Culture since 1945, Amsterdam: Rodopi, 2000. 
was expected to exhibit a certain national flair. The new crime series, as milieu studies and novels of customs and mores, have specialized in international background and location studies, becoming the exponents and chroniclers for the settings of their plots. In Robert van Gulik's series about Judge Dee, published from 1949 to 1968, we find an early example of the geographically determined crime series that came into being after 1945 - it created the Chinese detective novel. ${ }^{14}$ The Judge Dee detective stories are set in China in the Middle Ages and are derived from the reports of a seventh-century regional judge. The narrative themes, plots and criminal types draw on the rich, culturally specific Chinese context and Chinese history. Today's reader is introduced to the world of Taoism, swords, princesses, temples and monasteries. In this connection, it is significant that van Gulik, a Dutchman, tells his story from the perspective of an outsider, for the narrative thereby enters into the domain of travel writing. In other, subsequent series, the seemingly necessary alien perspective continues to be a mechanism that endows the new crime novel with a touristic character. Even the publishers' marketing blurb for successful crime novels today draws on the nomadic biographies of authors who travel throughout the world, authors like Henning Mankell, the Swede living in Mozambique, and Giorgio Scerbanenco and Donna Leon, the Russian and American living in Italy.

Gradually, topographic references are becoming ever more exhaustive, profuse and detailed. The range of investigators and detectives operating at a national level is being expanded and completed. Batya Gur's Michael Ochajon and Vázquez Montalbán's Pepe Carvalho have already achieved autonomy as literary figures and, like Miss Marple and Sherlock Holmes, represent the different national habits and quirks of Catalonia and Israel, their respective countries of origin. In crime novels and series, the heinousness of crime is increasingly being replaced by the search for more colourful settings and, by

14 See, for instance, Robert van Gulik, Oudejaarsavond in Lan-fang (New Year's Eve in Lan-Fang), 1958; Het Chinese lakscherm (The Lacquer Screen), 1962; Zes zaken voor rechter Tie (Judge Dee at Work), 1961 (all The Hague: Van Hoeve). See also Hartmut Walravens, "Richter Di bei der Arbeit: Zu Robert von Guliks chinesischen Kriminalromanen", in Orient extremus. Zeitschrift für Sprache, Kunst und Kultur der Länder des fernen Ostens, XXXVI/2 (1993), 223-34. 
means of a specific local connection, the crime novel takes on the function of a new type of Heimatroman. ${ }^{15}$

Among the works with the more exotic settings are the detective stories of the journalist Tony Hillerman which derive from the author's interest in the conditions, the histories and the rites of the Navajo on their reservations. In these ethno-thrillers, the thrill of discovery supplements the thrill associated with the detective story itself; it is paratextually supported by maps of Anasazi Country or regions in Colorado. The plots of the entire series are based on the Navajo people's cultural conflict with the United States government, which even extends to judicial concepts. In solving their cases, the detective duo of Lieutenant Leaphorn and Jim Chee always have to take both cultures into account. In Hillerman's A Thief of Time, they become involved in a search for a vanished anthropologist while at the same time pursuing grave robbers and researching the anthropology of Navajo law. ${ }^{16}$

The new crime novel is also distinguished by a sort of outward internationality that can be discerned in the reception of thrillers. Some authors such as Donna Leon, Henning Mankell and Elizabeth George have an international audience and their books have been translated into many languages. The internationality of crime in fiction is accompanied by the real international popularity of the crime novel, which makes its readers into a community of conspirators. ${ }^{17}$ While the internationality of crime fiction is due in part to book marketing and publishing house strategies, it is also due to the narrative strategies

15 Heimatroman can be translated as "homeland novel", although the concept Heimat is traditionally much more emotionally and ideologically loaded. It stands for everything that the home locality involves - such as types of buildings, traditional costumes, customs and values, local dialects - with an emphasis on rural rather than urban life. It can also be understood in the sense that it is used by the ethnologist Clifford Geertz, as the primordial tie to an ethnic group (Clifford Geertz, The Interpretation of Culture: Selected Essays, New York: Basic Books, 1973).

16 Tony Hillerman, A Thief of Time, New York: Harper Collins, 1988. For further discussion of Hillerman's work, see the essay by John Scaggs in this volume.

17 The supporters also present themselves on the internet in reader and fan pages. See, for example, a detective story forum and a crime database at the following site, http://www.krimi-forum.de. See, also, a fan page for Henning Mankell at http://www.buecher4um.de/AutorHM.htm, and a page by Valerie Wilson Wesley at http://www.tamarahayle.com. 
used in the portrayal of local settings. It is precisely the characteristic element of the surroundings at the scene of the crime that contributes significantly to the success of these novels.

\section{The paradox of the series}

Deep within our crime fiction world as it comes alive in books and in film, there is a paradox that is hardly noticed any more. The unusual occurrence of murder has become the norm. The extensive production of crime series and the frequency with which they come into being have made capital crime into an everyday event. We have an uninterrupted daily supply of corpses, crime motives and convicted criminals, from the regular Monday detective thriller through the new Mankell to Tatort, the show that has been a mainstay of the weekend broadcasting programme for West German television for the last twenty years. ${ }^{18}$

When there are murders waiting for us around every corner, the predetermined course of events in the plot becomes ever more stereotypical, the variations in crime motives, murder weapons and murderers' profiles ever more transparent. Audiences too can use a matrix to see how things are going to work out:

Motive: passion, jealousy, fanaticism, humiliation, self-defence, greed, vanity, anti-Semitism.

Murderer: psychopath, abandoned woman, head of the investigating agency, abused child, female rival, sect, drug lord, outcast.

Investigator: amateur with moral obligation (lawyer, barrister, journalist, priest), the duo, female private detective, commissioner, pathologist, competing investigative agencies (FBI against the local police).

Victim: mistaken identity, chance victim, deliberately murdered victim, prominent victim, vanished victim, victim of mass murder, feigned victim.

Scene of the crime: public spaces (park, crowd, lift) and private spaces (shower, bed, TV lounger).

18 See the illustrated book by Holger Wacker, Tatort: Krimis, Köpfe, Kommissare, Berlin: Henschel, 1998, which offers a topographic overview of the German Tatort series. 
Weapon: dagger, edge of table, poison, fist, cement mixer, fall out of a window, machine gun. ${ }^{19}$

The enigmatic riddles of the detective stories of yore, which kept their secrets until the final pages, have given way to crossword puzzles in which the same combinations of letters always repeat themselves. The investigation works with stereotypical sentence patterns: "Did the deceased have enemies?", "Where were you between one and three in the morning?", "Put the gun down, you're only going to make things worse for yourself." Serial production of detective fiction turns murder into a banality. Current headlines quickly turn up in crime stories: white-collar crime, computer crime, racism and xenophobia, smuggler criminality and white slaving are quickly processed. ${ }^{20}$ While real massacres, like those in sects' houses or in schools such as Littleton in 1998 or in Erfurt in the eastern part of Germany in April 2002, prove the impossibility of controlling crime - bank raids and kidnappings in kindergartens turn into live media events. The boom in crime fiction can be understood as a reaction to the hysteria of crime in real life: the relief of tension supplied by the resolution of criminal intrigues in literature and in film stands in reverse proportion to the media's presentation of spectacular crimes and their uncontrollability.

\section{The macrocosm of the scene of the crime: culture and society}

Even in fiction, film and the modern fairy tale, a daily murder ritual becomes boring in the long run if there are no other elements of suspense. These are created when the foreseeable riddle of the whodunnit is replaced by mysterious surroundings that the investigative troops

19 I thank Nicole Weiß, Sylvere Mbondobari Ebamangoye, Christoph Schulz and the summer 1998 Seminar on Detective Fiction at the Department of General and Comparative Literature at the University of Bayreuth for many references and for collaborating on a project to create a comprehensive schema of crime fiction topoi. The work on this essay is also linked to the Crime and Nation project, carried out with Immacolata Amodeo.

20 See, for example, the film Sperling und der brennende Arm (Germany 1997/98, director Dominik Graf, script Rolf Basedow), an Albanian thriller set in Hamburg that deals with the Mafia methods of Albanian exiles in Germany, which was awarded the best television movie prize by the Deutsche Akademie der Darstellenden Künste in 1999. 
explore; knowledge of the local environment becomes the fundamental competence necessary to investigative work: "Only a native could successfully follow another person through the narrow streets of the city; only a native would know the sudden stops, the hidden turns, the dead ends." ${ }^{21}$ If Auguste Dupin began his analyses from the armchair and arranged his hypotheses in a logical chain of statements, today's social thriller definitely takes place at the scene of the crime. The reading of crime novels becomes an ethnographic reading; the scene of the crime becomes the locus genius of the cultural tragedy.

At first glance, in the context of the continuing topicality of migrations, multiculturalism and postcolonialism, which have challenged uni-dimensional cultural and national identities, this narrative strategy is surprising. However, it is precisely in societies that produce theoretically highly complex discourses on multiculturalism, and in societies that regard multiculturalism as part of their political selfunderstanding and their national identity, like the USA and Israel, that interest in the status of nationality is returning. ${ }^{22}$ In Europe, where the historical formation of nineteenth-century nation building is itself becoming history, there is growing affirmation, even a sort of reanimation of the culture of nationality. ${ }^{23}$ In the second half of the twentieth century, gradually at first, and then increasingly, as the boom in crime fiction took off, the pursuit of the criminal was displaced by the search for cultural identity. The genre of crime fiction has thus thematically returned to the tradition of the search for identity of classical antiquity, as typified by the crime of Oedipus Rex, where the murder of the king sets in motion a process of questioning and revelation of identity.

Now that capital crime cases and their guaranteed solution have become normality in books and films in the twentieth century, it is the fictional world of victims, suspects, detectives and commissioners that

21 Donna Leon, Acqua Alta, London: Pan, 1997, 241.

22 See David A. Hollinger, Post-Ethnic America: Beyond Multiculturalism, New York: Basic Books, 1995; and Pheng Cheah and Bruce Robbins, Cosmopolitics: Thinking and Feeling beyond the Nation, Minnesota: University of Minnesota Press, 1998.

23 On the hypocrisy of the multicultural discourses of postmodernism and on the connection between multicultural and nationalist discourses, see Slavoj Žižek, Liebe Deinen Nächsten, nein danke! Die Sackgasse des Sozialen in der Postmoderne, Berlin: Volk und Welt, 1999, 5-21. 
is to generate new suspense. The criminological search for the trail of evidence is transposed to epistemologies of cultural anthropology, ethnographic and national characteristics, and the structure of the genre is governed by the spectrum of cultural identities. The new crime novels are characterized by their variously staked out territorial contexts that encompass ethnic groups, nations, regions, provinces or cities, but only by degrees. The distinguishing feature that they share remains the representation of the territory and its cultural conditions. ${ }^{24}$

In today's crime novels, milieu studies ranging across the world no longer seek to create an experience of alterity exclusively in the uncanny nature of the crime which would be resolved in a happy ending that provides a return to normality and justice, instead they seek such an experience in local cultures alien to the reader. The effect of the étrange, the strange and uncanny, as evoked in the double murder in Edgar Allan Poe's The Murders in the Rue Morgue, has been gradually shifting since the middle of the nineteenth century to the point where it has now been replaced by the effect of the étranger, the unfamiliar and alien. ${ }^{25}$ In the development of the genre, crime is taking a back seat to the representation of alterity, which implies an almost embarrassed hiding of the experience of identity.

Now the search for experiences of alterity and identity is by no means culturally specific, but universal. From a perspective of postmodernism - the standpoints and practices of which were the subject of debate at the same time as the boom in crime fiction was taking off, and which accompanied it theoretically - (Western) identities were at the top of the agenda because of the perceived loss of collective and social structures, the loss of biographic certainties and the fragmentation of life stories. While literary theory and cultural criticism in the late twentieth century questioned the basic features of identity, that is, gender and nationality, as historical constructs, crime fiction sought to

24 Karl Heinz Kohl points out that there are no hierarchies among these elements. Even in the twentieth century, ethnicity is not an alternative to nationalism. Kohl identifies "ethnic group" as a technical term and an ideological construction (see Karl Heinz Kohl, "Ethnizität und Tra dition aus ethnologischer Sicht", in Identitäten: Erinnerung, Geschichte, Identität 3, eds Aleida Assmann and Heidrun Friese, Frankfurt am Main: Suhrkamp, 1998, 282).

25 The orangutan and the strange voices that the witnesses cannot identify are both the components of the étrange-étranger contained in The Murders in the Rue Morgue (1841). 
affirm a sense of national and gender identity all the more intensively. While theory deconstructed identities, crime fiction restored them to wholeness; indeed, it succeeded in giving parity to satisfying both the need for identity and the need for alterity. With its narrative detail in which the outlines of the criminal cases are lost in the minute documentation of everyday life in a foreign country, crime fiction retains that postmodern indecisiveness in which attempts are made to deal with ambivalent identities. ${ }^{26}$ Sociology and cultural criticism diverge in the assessment of this ambivalence of defining what is one's own and wanting something alien as well. The fans of crime fiction differ in this question too, what some readers experience as familiar and beloved is unutterably boring for others. One crime author says:

Of course I have often wondered why Kurt Wallander is so popular. I dare say that it's due to the content of the books. They deal with things that concern many people, but I believe it also has to do with the fact that Wallander himself is continually changing, like you and me. The literary credibility lies in the fact that one describes a person's inconsistency. I personally detest the sort of book where I know all about a figure after a few pages and after that, no more changes occur. By contrast, Kurt Wallander is quite different in the seventh book to what he was in the first one. That makes him believable, since to that extent, he is similar to us. ${ }^{27}$

A reviewer says:

There can be no doubt about it, people read Mankell because they want to be bored, because they feel at home with his very bureaucratic language, which strings together trivialities without rhyme or reason, and when pretending to go into something deeper, only repeats itself shamelessly. People like Wallander because he is like them. ${ }^{28}$

26 See Etienne Balibar and Immanuel Wallerstein, Race, Nation, Class: Ambiguous Identities, London: Verso, 1991.

27 Henning Mankell, "Ein Fuß im Schnee und einer im Sand", available at the following site: http://www.schwedenkrimi.de/mankell_vortrag.htm.

28 Gerd Friedrich Marenke, "Die Ödnis der schonischen Ebene", 2003, available at the following site: http://www.kaliber38.de/features/marenke/mankell.htm. 


\section{Nationality as folklore}

How can one make a place that is narrowly circumscribed interesting for a wide, potentially international audience? This is achieved by having recourse to cultural stereotypes and clichés that are affirmatively used, ironically used or problematized. The clichés that are best known worldwide are national stereotypes, with which crime fiction most often plays. National characteristics are embroidered upon for the representation of fictional figures; thus, the distinguishing feature of Scottish or Greek crime fiction is not that it is written by a Scot or a Greek, but that it attempts to convey a Scottish or a Greek atmosphere.

The most popular example of internationally read crime novels is the Commissioner Brunetti series by the American Donna Leon; the volumes are numerically subtitled. ${ }^{29}$ His investigations are set in Venice which, because of its island setting and because it has for centuries been favoured by newly-weds, is seen as the most Utopian of cities in European cultural history. Brunetti's cases take place against the backdrop of an italianità in which the Mafia, the opera, the palazzi, art and patrician history reappear in the narrower context of a venezianità in which the canals, the bridges, the carnival and even the tourists (the readers) come into play. ${ }^{30}$ There is method in the author's recourse to national stereotypes, which is not confined to the italianità of the Italian protagonists but also extends to many minor characters of foreign extraction. If they come from Germany, like the conductor Hellmut Wellauer in Brunetti's first case, Death at la Fenice, the solution lies in the dark Nazi past; files requested from Germany show German thoroughness, while one never understands the languages of the Romanians and Bulgarians, etc.

In much the same way as travel guides give foreigners basic linguistic help, Leon's insertion of Italian sentence and word fragments

29 Donna Leon, Death at la Fenice, London: Chapmans, 1992; Death in a Strange Country, London: Chapmans, 1993; A Venetian Reckoning, London: Macmillan, 1995; Acqua Alta, London: Pan, 1997; A Noble Radiance, London: Heinemann, 1998; Wilful Behaviour, London: Heinemann, 2002.

30 Donna Leon has forbidden the translation of her work into Italian and thereby has specified her target readership as those who do not know Italy. It is primarily for the Americans and Europeans outside Italy that these crime novels have been written and for whom the rudimentary cultural anthropology and Italian local colour have been introduced. 
and her explanation of these is part and parcel of the repeated thematization of national idiosyncrasies. It is sometimes useful and sometimes very specific. Examples from Acqua Alta are:

Obviously, Signora Petrelli had been at work on the hospital staff, seeing that the little envelopes, bustarelle, were delivered into the proper hands. (39)

"Pantegane", he explained, giving the Venetian name for rat, a word which, though it named them clearly rat still managed to make them, in the naming, somehow charming and domestic. (61)

The first one turned to the barman and said, "Due vanilla and chocolatto, please." (77)

His hand was underneath his jacket, pulling at his revolver, when they heard Flavia shout, "Porco vacca", and then both of them heard the unmistakable sound of champagne splashing from the neck of a bottle on to the floor. (144)

"Ricca sfondata", she explained. Bottomless riches. (155)

I did some business with him when he first opened his shop here, years ago, and he's un vero figlio di puttana. (173)

"Buon giorno?" he called ... (198)

The novels of Leon do not supply the only examples of national stereotyping, but they certainly provide the clearest. These stereotypes often help to solve the cases. Reading the Venetian cases, an obviously problematic interculturality becomes evident, which, in spite of a myriad of national differences (Britons, Chinese, Sicilians, Romanians, Neapolitans and Americans are all represented), is nevertheless accepted. If the characteristic classifications prove correct, then the investigation proceeds, but ambiguous cultural classifications confuse the Commissioner: "The French, Brunetti knew, had conquered Naples centuries ago, but the usual genetic souvenir of their long occupation was the red hair sometimes seen in the city, not these 
clear, Nordic eyes." ${ }^{\prime 1}$ The national distinctions eventually even disappear behind the sole dividing line between "foreign" and "local" 32 that strikes one as stubbornly traditional and which would be anachronistic in the twentieth century, if it did not derive, as it probably does, from the American author's tourist view of Europe. One might think, however, that even in Europe, the humorous description of southern Italians as "immigrants in their own country", ${ }^{33}$ and the emphasis on Venetians by birth as the legitimate residents of Venice belong to the national conflicts of the past.

However, this naïve repetition of national characteristics becomes interesting once more in the context of the globalization, not least of book markets, that relieves the individual nation states of their political and economic decision-making power and renders the nation state with its distinctive features a collection of individual and local quirks. In the global village, nationality may be cultivated as folklore. The thematization of national characteristics in crime fiction becomes more interesting too when well-known stereotypes are observed from a new perspective and well-known clichés updated. For example, the Spanish-Catalan gourmet Carvalho ironically comments on and parodies national stereotypes in the course of his investigations. The Carvalho novels also show that the alien perspective, if it is not carefully adjusted, cannot produce the defamiliarization of cultural stereotypes when they give superficial treatment to well-known topoi such as the Mafia. Certainly, Vázquez Montalbán too has recourse to clichés relating to Spanish society's formation of national identity for example, the history of the Communist party or Catalan national pride, but he does so in order to examine them critically on a cultural and ideological level. Spain's coming to terms with its past becomes a running gag in his book-burning motif.

The interest in the discourse of nationalism, which can be seen as a desire to come to terms with nationality and identity crises, is an intercultural one. Such interculturality may serve to relativize and counterbalance the "Unterscheidung von Nationen" (distinguishing of nations

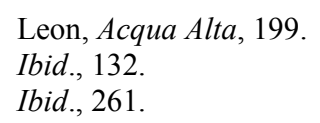


from each other).$^{34}$ Although individual works of crime fiction have recourse to specific cultures (in Israel to the conflict in Palestine, in post-Franco Spain to coming to terms with the era of the dictatorship, in Australia to the funeral rites of the Aborigines), the interculturality that the works of this genre have in common lies in relativizing the significance of the national. The interculturality of current crime fiction is based on the need of the inhabitants of a global village for similarly global, ethnographic and anthropological general knowledge.

Throughout the world, the genre of crime fiction has assumed the task of describing local cultures and, in addition to the constant restoration of justice, does the work of cultural representation. This comprises the imagological representation of national stereotypes and critical reflection of and upon different milieus and socio-political ideologies, as well as the portrayal of the historical conflicts of individual societies and states.

Within contemporary crime narrative, as the dual narrative strands of crime and investigation come together in the resolution, the reader is offered yet another strand, that of cultural investigation, the inclusion of which constitutes an important shift within the genre. In certain novels the resolution of the murder can be seen to coincide with a restoration of cultural order, whereas in other cases these very orders are questioned.

Although in this regard there is great diversity in current crime writing, there is no contradiction in crime novels with markedly national plot settings being internationally successful. Given the natural desire for the acquisition of general knowledge on the part of the reader, it is logical that a genre dedicating itself increasingly to the fictional description of local cultural knowledge should prove exciting to a wide readership. In the last thirty years crime fiction has gained worldwide currency in two different ways. It has encompassed the globe in terms of its reception, and in terms of its content it has, on an equally global scale, been concerned with the narrative investigation of murder cases in all corners of the earth. At the beginning of the twenty-first century it reflects within a globalized world those local

34 Niklas Luhmann, Die Gesellschaft der Gesellschaft, Frankfurt am Main: Suhrkamp, 1998. 
milieus and topoi which are now generating fresh excitement and interest. $^{35}$

35 This essay has been translated by Fiona Fincannon. 